\title{
Philo of Alexandria on the twelve Olympian gods
}

abstract: The importance of pagan philosophy and literature for Philo's thinking has long been acknowledged. What is less studied, however, is his attitude towards the individual gods of the Greek pantheon, and this is the topic of the present article. After a brief discussion of Philo's critical stance towards Greek polytheism in general, a first survey of relevant material is provided that already allows for a few provisional conclusions. This is followed by a more detailed analysis of the argumentative strategies which Philo uses while dealing with the Olympian gods. This analysis shows that Philo adopted a quite sophisticated and strategic position towards the Olympians: while there can be little doubt about his negative view, he as a rule avoids straightforward criticism of particular gods and prefers to either ignore them or cleverly reorient them towards his own Scriptural perspective.

1. Philo and pagan culture

What has Athens to do with Jerusalem? The answer to Tertullian's famous question (Praescr. haer. 7,9; CCSL p. 193.32-33) is far less easy than its author suggests. For Tertullian, the only correct answer is a straightforward "Nothing of course," since the Christian faith has no need at all of over-sophisticated pagan philosophy. But Tertullian's rhetorical question cleverly masks that such a view may well be oversimplified. Many contemporaries were less confident, opted for a more nuanced position, or even underscored the intimate connection of the two poles. And some even regarded Plato as an Atticizing Moses, ${ }^{1}$ thus replacing one extreme view by another.

Philo of Alexandria would perhaps not go that far, but he certainly belonged to the group of 
thinkers who pursued a reconciliation of the Jewish Scripture and the pagan tradition. The importance of the former appears from nearly every page of Philo's voluminous oeuvre, whereas the significant influence of the Greek intellectual tradition on Philo's thinking has often been demonstrated in secondary literature. ${ }^{2}$ An interesting passage in this respect is Congr. 7980:

T1 And indeed just as the school subjects ( $\tau \dot{a} \varepsilon \dot{\varepsilon} \gamma \varkappa \dot{u} \varkappa \lambda \iota a)$ contribute to the acquirement of philosophy, so does philosophy to the getting of wisdom. (...) And therefore just as the culture of the schools is the bond-servant of philosophy, so must philosophy be the servant of wisdom. ${ }^{3}$

Here Philo develops a clear-cut threefold hierarchy. On the one hand, encyclical knowledge is regarded as the servant of philosophy. From such a point of view, the whole field of mathematics and music, of grammar and rhetoric, and so on, can contribute to the acquirement

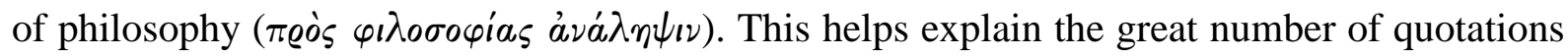
from and references to ancient pagan authors in Philo's works. ${ }^{4}$ On the other hand, philosophy is not an end in itself, but is considered the servant of wisdom - that is, the wisdom of Scripture, for philosophical thinking indeed provides Philo with the hermeneutic key for the understanding of Scripture. This explains the massive input of philosophical doctrines in Philo's exegesis, especially from Plato ${ }^{5}$ but from other schools as well. ${ }^{6}$ It is the Scriptural perspective, however, that in the end determines which philosophical views are correct.

This threefold hierarchy is conceptually crystal-clear and reflects the core of Philo's reception of the Greek pagan tradition. In that sense, $\mathrm{T} 1$ provides this article with its general interpretative framework. At the same time, however, this schematic framework leaves out the versatile creativity and multifaceted inventiveness of Philo's thinking. There can indeed be 
found many concrete cases in which the above strict hierarchy is less clear than the conceptual scheme suggests, and several studies have shown that Philo's reception of the pagan tradition can be very subtle indeed. Material from Homer's Iliad and Odyssey, for instance, is appropriated in various ways, even in contexts where the direct relevance for a correct understanding of Scripture is not evident ${ }^{7}$ or where it even interferes with Philo's exegesis. ${ }^{8}$ In that sense, $\mathrm{T} 1$ offers a general perspective that remains valid in principle, but that also leaves ample room for ingenious adaptations and reorientations of traditional pagan material.

In this article, this is further illustrated by an analysis of Philo's view of the twelve Olympian gods. This is an aspect of his reception of the pagan tradition that has a yet not been systematically examined. The above mentioned interpretative framework derived from T1 suggests that the role of the Olympian gods in Philo's oeuvre is very limited. For what can indeed be their role in a perspective that is thoroughly conditioned by Jewish Scripture? This can only be a negative story: we may expect either vitriolic attacks or deafening silence. As a matter of fact, the relevant passages from Philo's works tell a different story. In what follows, I'll investigate where Philo mentions the twelve Olympian gods (section 3) and on which argumentative strategies his view of them is based (sections 4 and 5). But first I'll have a look at the broader perspective from which his statements about individual Olympian gods should be understood by briefly examining his criticism of polytheism in general (section 2).

2. Philo and polytheism

Philo indeed repeatedly rejects polytheism, which is opposed to the Jewish belief in the one true God. ${ }^{9}$ Polytheism is closely connected with atheism, ${ }^{10}$ it is a cause of quarrelling and fighting, ${ }^{11}$ and it is more proper to a beast than to rational human beings. ${ }^{12}$ The most important passages in this context are Decal. 156 and Heres 169. In the latter, Philo argues that polytheism 
is diametrically opposed to the first commandment of the Decalogue. In the former, he observes that the second commandment forbids not only the making of idols but

T2 also the acceptance of fabulous legends ( $\left.\mu \dot{u}^{\prime} \nu \nu \nu \pi \lambda \dot{a} \sigma \mu a \tau a\right)$ about the marriages and pedigrees of deities and the numberless and very grave scandals associated with both of these.

Here we find the very core of Philo's position towards pagan polytheism. All mythological stories about the gods are rejected because they are at odds with the fundamental truth of Scripture. It is clear that T2-although it has a more specific focus-is perfectly in line with the hierarchy elaborated in T1. The decisive argument against polytheism is not the traditional Platonic criticism of the poets and their silly lies, but Scripture. From the perspective of the Decalogue, the traditional stories appear as $\mu \dot{\imath} \imath \omega \nu \pi \lambda \dot{a} \sigma \mu a \tau a$. This is a well-known phrase that very often occurs in Philo's works, usually in the context of an opposition between myths and the truth. ${ }^{13}$ We may conclude, then, that all the stories of the Olympian gods are only deceptive fabrications of myth-makers.

Yet precisely the authority of Scripture induces Philo to a less apodictic position. In the Septuagint translation of Exodus 22:28, we read that we should not abuse the gods (શrov's ou

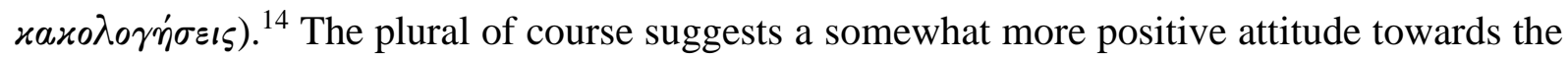
gods of polytheism. In $Q E x$ 2.5, Philo discusses this Septuagint passage in detail and makes the following three observations:

T3 [1] Do they [viz. the opponents of the Jews] then still accuse the divine Law of breaking down the customs of others? For, behold, not only does it offer support to those of different opinion by accepting and honouring those whom they have from 
the beginning believed to be gods, but it also muzzles and restrains its own disciples, not permitting them to revile these with a loose tongue, for it believes that wellspoken praise is better. [2] In the second place, those who are in error and are deluded about their own native gods and because of custom believe to be inerrant truth what is a falsely created error, by which even keen and discerning minds are blinded, are not peaceful toward or reconciled with those who do not gladly accept their (opinion). And this is the beginning and origin of wars. But to us the Law has described the source of peace as a beautiful possession. [3] In the third place, he who speaks evil (of others) must of necessity receive the contrary reproach in similar matters. Accordingly, those who have in mind a concern for dignity will refrain from reviling other gods, in order that the power of the truly certain and existent (God) may be well spoken of and praised in the mouths of all. For (thus) we shall seem not to be hearing but to be speaking, as others use our voice. For there is no difference between saying something oneself and inviting others to say it in any way.

This interesting passage deserves to be quoted in full because it throws light on several important aspects of Philo's position towards the Olympian gods (and towards polytheism in general). As such, we will repeatedly return to it in the course of our study. First of all, it shows that Philo's position to an important extent rests on strategic pragmatism. Philo here indeed advocates a careful and tactful approach that avoids direct confrontation. The first observation in T3 even sounds like a kind of captatio benevolentiae that can be addressed to a pagan audience: that the Jews have a great respect for pagan gods can be proven on the basis of the Jewish Scripture itself. Such diplomatic caution reflects at least to a certain extent the historical situation of the Jews in Alexandria. The pogroms described in On the Embassy to Gaius and 
Against Flaccus are a telling illustration of the relevance of this approach.

But Philo's position does not merely rest on political pragmatism and conformism: it is also rooted in a careful exegesis of Scripture. And this exegesis concerns the literal meaning of the Scriptural passage: there is no trace of an allegorical interpretation here. Philo also makes it very clear that polytheism is completely wrong: the pagans are "in error and deluded about their own gods", they believe a "falsely created error", contrary to the Jews who worship the "truly certain and existent God". Discretely avoiding abuse of the gods thus does not imply endorsing polytheism. Finally, observing this commandment yields a further theological advantage as well, as it creates goodwill among the pagans for the true God. Somewhat paradoxically indeed, by not abusing other gods, a Jew directly contributes to the praise of his own God. Philo makes basically the same point in Spec. $1.53 .^{15}$

It is clear, then, that $\mathrm{T} 3$ provides an important complement to $\mathrm{T} 1$ and $\mathrm{T} 2$. It does not undermine the fundamental hierarchy of encyclical knowledge, philosophy and the wisdom of Scripture, for here as well the latter remains the ultimate and authoritative source of the truth, as appears from the explicit rejection of polytheism. Yet this rejection is combined with a certain tactful 'benevolence' towards the pagan perspective, a benevolence which is likewise justified on Scriptural grounds. This subtle attitude will more than once reappear in Philo's statements about the individual Olympian gods. There, we'll find a broad scale of comments, from utter rejections to a much more positive evaluation. At this point, we can have a closer look at those passages where Philo deals with the Olympian gods.

\section{A first survey}

The following list contains all the passages where Philo refers to the twelve Olympian gods: 


\begin{tabular}{|c|c|}
\hline Zeus & $\begin{array}{l}\text { Opif. 100; Deus 60; Plant. 127-29; Legat. 188; Prob. } \\
\text { [19], 102, } 127 \text { and 130; Aet. 81; Prov. 2.15, 17, 25, 35, } \\
\text { 37, 39, 46, 80, 89, } 91\end{array}$ \\
\hline Hera & Decal. 54; Cont. 3; Prov. 2.40 \\
\hline Poseidon & Decal. 54; Cont. 3 \\
\hline Demeter & Opif. 133; Spec. 3.40; Cont. 3; Decal. 54 \\
\hline Hermes & Decal. 54; Legat. 93-102; Prob. 101 \\
\hline Athena & Opif. 100; LA 1.15; Mos. 2.210 \\
\hline Ares & Legat. 93, 97, 111-13 \\
\hline Aphrodite & Decal. 54; Cont. 59; Prov. 2.40 \\
\hline Apollo & Decal. 54; Legat. 93, 95, 103-110 \\
\hline Artemis & Decal. 54; Aet. 37 \\
\hline Hestia & Cher. 26 \\
\hline Hephaestus & Decal. 54; Aet. 68 and 127; Cont. 3; Prov. 2.40 \\
\hline
\end{tabular}

This list already shows that the Olympian gods are rather seldom mentioned by Philo. Moreover, several passages appear more than once in the list (esp. Decal. 54 and Cont. 3), and others are hardly relevant. In Prob. 101, for instance, the reference is to Hermes as a character in a Satyric play of Euripides. In Aet. 81, Philo refers to the Stoic view of Zeus, in Prob. 102 to a passage from Euripides, and in Prob. 127 to Heracles 'son of Zeus.' In the second book of $O n$ providence, Zeus' name is frequently mentioned, but often in quotations from earlier pagan authors $(17,25,80$ and 89). Cont. 59 refers to the doctrine of the two Aphrodites in Plato's Symposium: this is an interesting passage about Philo's reception of the Platonic dialogue, but is hardly relevant in our context. In Aet. 37, finally, Philo refers to a Homeric verse about Artemis but omits every clear reference to the goddess. If all these passages are omitted, there is little that remains. Philo knows the twelve Olympian gods, of course, but they are hardly relevant for his thinking. At that, we may add, is no great surprise. It may help, though, to put 
things in their correct perspective. Whereas Moses is omnipresent in Philo, Zeus is not, and this is fully in line with Philo's rejection of polytheism in general.

What is more surprising, perhaps, is that specific Olympians are almost never criticised by Philo. He apparently loyally and quite systematically observes the above mentioned Exodus commandment of 'not abusing the gods.' Nowhere indeed does he attack the conduct or the person of a particular Olympian god. ${ }^{16}$ Similarly, he as a rule avoids criticism of traditional cults of the gods. There are only two exceptions. In Spec. 3.40, he attacks effeminate men who act as leaders of the mysteries and initiations and celebrate the rites of Demeter. The context is a more general attack against pederasty and its excrescences, and Philo is especially blaming the unworthy men, rather than the goddess. In Cher. 91, he more generally rejects the festivals ( $\pi a \nu \eta \gamma \dot{v} \varrho \varepsilon ı)$ ) of the Greeks and barbarians:

T4 Different nations, whether Greek or barbarian, have their own, the product of myth and fiction ( $\dot{\varkappa} \mu \nu \mathcal{\imath} \varkappa \tilde{\omega} \nu \tau \lambda \lambda a \sigma \mu \dot{a} \tau \omega \nu)$, and their only purpose is empty vanity. We need not dwell on them, for the whole of human life would not suffice to tell in

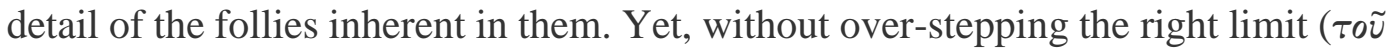

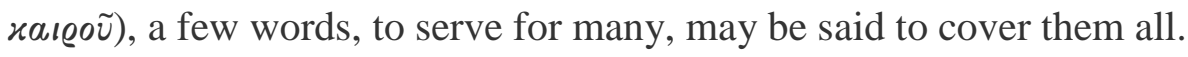

In what follows (Cher. 92-97), Philo indeed launches a lengthy attack against widespread vicious practices that can often be observed during such festivals, but this is the only passage in Philo's voluminous oeuvre where such an attack is to be found. Niehoff concludes that Philo was simply not interested in pagan cults. ${ }^{17}$ On the basis of T3, we might rather argue that Philo's general attitude towards pagan cults shows the same pragmatic caution as his attitude towards the gods. Both explanations need not exclude one another of course, but the above quoted passage from On the Cherubim shows that a third element is important as well. Philo begins by 


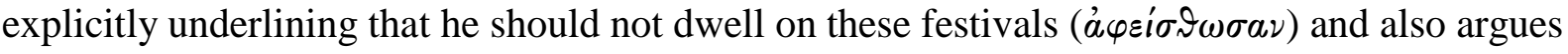
why this is so: even his whole life would not suffice to deal with the issue in detail. Yet this rhetorical hyperbole is not Philo's last word on the topic, for he immediately adds that a few words are in place, provided that they do not miss the right moment. The term xaıos is of paramount importance here. In this context it introduces the concern for the relevance of the topic. Every reader of Philo knows that the author is not afraid of (lengthy) digressions, but T4 shows that there should always be a link between the digressive passage and the main topic under discussion (even though that link may be associative). In this specific case, we can be

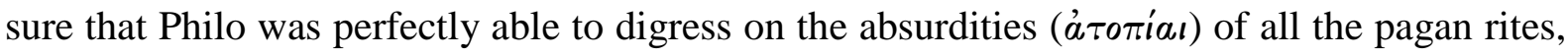
but such a digression would soon develop into a separate treatise that cannot easily be introduced into his exegesis of a particular passage from Scripture. ${ }^{18}$ We may conclude, then, that the general absence of attacks against pagan rites is not merely a matter of lack of interest or pragmatism, but also of concern for the thematic relevance of the topic in the context of Philo's exegesis of Scripture.

4. Olympian gods in the service of Scripture

At this point we can conclude that Philo's attitude towards polytheism rests on three leading principles: Scripture as the ultimate authoritative criterion of truth (T1 and 2), a certain pragmatism and diplomacy based on Scripture (T3) and the relevance of the topic for his own authorial purposes (T4). We should now turn to concrete passages about individual Olympian gods in order to examine what strategies Philo uses when dealing with them.

\subsection{The Olympians from an allegorical point of view}


If Philo as a rule indeed avoided harsh criticism of the Olympian gods, we may expect that he favoured an allegorical approach in order to explain them away. After all, his fondness for allegorical interpretations needs no further comment. And indeed, in Prov. 2.40, he points to the allegorical interpretation as the appropriate approach to read the poets. Whereas his nephew Alexander has argued that Homer's works are full of lies and that he presents Hephaestus as lame (Il. 18.397, 411, 417; 20,37; Od. 8.308 and 332), Aphrodite as wounded and bleeding (Il. 5,336-540), and Hera as hanging among the clouds with two anvils on her feet (Il. 15.18-22) (Prov. 2.37), Philo replies that such passages should be understood allegorically: Hephaestus is fire, Hera air, and Hermes the logos (2.40-41). Such allegorical interpretations can serve as a

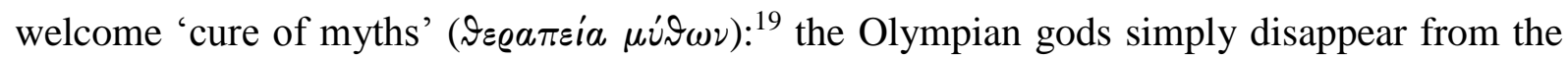
scene and are replaced by physical elements. If Hephaestus is just another name for fire, he no longer undermines the truth of Scripture.

A similar approach can also be found elsewhere in Philo. In Aet. 127, for instance, while dealing with the four elements, he observes that fire is extinguished as soon as it has lost its sustenance and connects this idea with the ancient poetic tradition: fire is lame, as the poets say

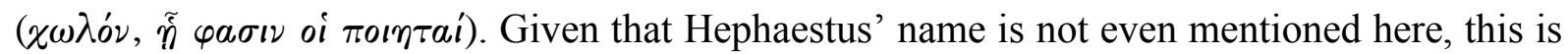
an example of a radically consistent use of the allegorical method as it is recommended in $\mathrm{On}$ providence. In $Q G 4.6$, Philo argues that the food that is fitting for the heavenly Olympians is "the desires and yearnings of the rational soul, which it uses for the apprehension of wisdom and the acquisition of perfect virtue." Here as well, we find basically the same approach. Nectar and ambrosia, the traditional food of the Olympian gods, are not even mentioned, and instead, we get a moral allegory that can perfectly be reconciled with the Scriptural perspective. Along the same lines, Philo points out that the sages obtain as their portion to live in the heavenly region of the Olympus (Somn. 1.151). Even when talking about the habitants of the Olympus, then, Philo manages to ignore the twelve Olympian gods. 
Such passages illustrate the interesting advantages of an allegorical interpretation. Allegory indeed makes it possible to neutralise and even use elements of the tradition concerning the Olympians in Philo's Jewish monotheistic perspective. Yet such an allegorical understanding of the pagan polytheistic tradition is rather exceptional in Philo's works. Even more, twice it is explicitly rejected. The locus classicus is Decal. 54-55, where Philo attacks those who deify the elements:

T5 Different people give them different names: some call the earth Korē or Demeter or Pluto, and the sea Poseidon, and invent marine deities subordinate to him and great companies of attendants, male and female. They call air Hera and fire Hephaestus, the sun Apollo, the moon Artemis, the morning-star Aphrodite and the glitterer Hermes, and each of the other stars have names handed down by the mythmakers, who have put together fables skilfully contrived ( $\varepsilon \tilde{\tau} \tau \varepsilon \tau \varepsilon \chi \nu a \sigma \mu \varepsilon \dot{\nu} a$ $\left.\pi \lambda a^{\prime} \sigma \mu a \tau a\right)$ to deceive the hearers and thus won a reputation for accomplishment in name-giving.

The traditional gods thus appear as fabrications of sophists, as deceptive inventions based on an allegory of natural elements. Needless to say that such views interfere with faith in the one true God. Yet once again, Philo here refrains from attacking the Olympian gods themselves. In that respect, he consistently maintains his usual tactful pragmatic attitude, as motivated in T3. Philo's main target are the wrong views of those gods, viz. the deification of natural elements. Such identifications of elements or celestial bodies with gods obviously invite an allegorical approach, but here, Philo emphatically rejects such a course. Precisely the same position returns in Cont. $3:^{20}$ 
T6 Can we compare those who revere the elements, earth, water, air, fire, which have received different names from different peoples who call fire Hephaestus because it is kindled ( $\left.\xi^{\prime} \xi a ́ \pi \tau \omega\right)$, air Hera because it is lifted up (al@ $\omega$ ) and exalted on high,

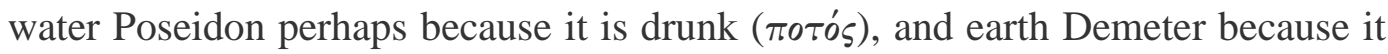
appears to be the mother ( $\left.\mu \dot{\eta}^{\prime} \tau \varrho\right)$ of all plants and animals?

This passage explains why the mythmakers mentioned in T5 won their reputation of excellent name givers. It now appears that their choices were not made at random, but rested on sophisticated etymologies. These etymologies can indeed be found in the tradition, ${ }^{21}$ with which Philo was apparently familiar. Yet this encyclical knowledge is assessed by the criterion of Scripture (following T1 and T2), and as a result, the physical allegory of the Olympian gods is again rejected as a product of sophists, far surpassed by the insights of the Therapeutae. This is no doubt Philo's fundamental position: as a general rule, we should not look for deeper meanings in polytheistic stories; they are simply wrong. ${ }^{22}$

\subsection{Grains of truth}

a) We may conclude so far that Philo was not particularly fond of allegorical interpretations of the Twelve Olympian gods. When he indeed mentions these gods, he usually focuses on the literal meaning of the stories about them. But even so, they sometimes prove to contain valuable insights.

A very important and much discussed passage in this respect is Somn. 1.233. There, Philo refers to an old story ( $\pi a \lambda a ı$ ๖̀ $\lambda o_{\gamma}$ os), which tells how the gods took on a human shape and then went from one city to another in order to observe the transgressions of men. ${ }^{23}$ Philo makes it

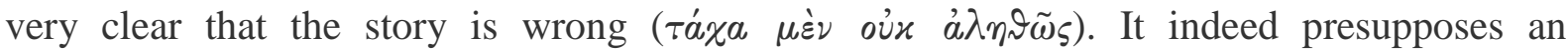


anthropomorphic interpretation of God, which is problematic in light of Philo's own theological thinking. The adverb ráxa ('perhaps') is quite remarkable in this respect, as it seems to suggest at least some doubts on a matter that is obvious. However that may be, Philo adds that the story, even if wrong, is at all events particularly useful. The shadow of doubt suggested by ráxa is immediately followed by the certainty of an emphatic $\pi \dot{a} \nu \tau \omega \varsigma$, further underscored by the

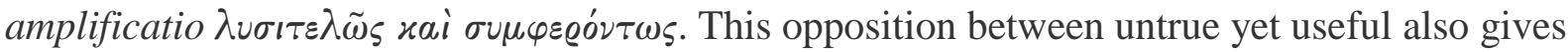
Philo's position an anti-Platonic ring, even more so since Plato himself criticised the same Homeric lines. ${ }^{24}$ For Philo, such a story may be useful for less talented people, who can only think of God in corporeal terms. In their case, old stories such like these may well contribute to their self-control. This argument is an interesting complement to T3. There, we saw that Philo's 'kindness' to the polytheistic tradition was at least partly rooted in pragmatic considerations. Here, the focus is on a pedagogical perspective. Even for moral pedagogical reasons, old stories

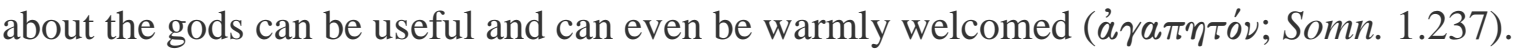

But Philo's reception of the story is even more subtle than this. What interests him in this old tale is the fact that the gods there have assumed a human shape. This, as we have seen, is the element that helps Philo to descend to the intellectual level of less gifted people. Precisely the same argument returns in Deus $51-69 .{ }^{25}$ There too, Philo regards the anthropomorphic image of God as false yet useful for less talented men. They "may well learn the untruth, which will benefit them, if they cannot be brought to wisdom by truth" (Deus 64). And in light of this, Philo changes the tradition on one significant point. Whereas Homer, the source of the old tale,

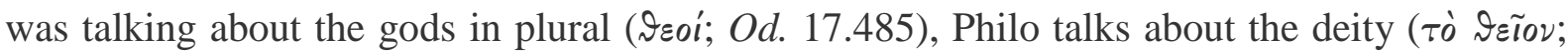
Somn. 1.233$)^{26}$ - a small and subtle change with far-reaching consequences. For by refashioning and reorienting the story towards a monotheistic perspective, Philo takes care that it serves exactly the purpose for which he wants to use it. When all traces of polytheism have been erased, the story can smoothly be introduced in Philo's moral pedagogy. The Olympians 


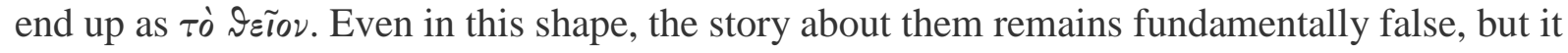
has at least become useful.

b) In other passages, Philo goes even further by suggesting (implicitly) that some stories about the Olympian gods even contain a kernel of truth. In such contexts, he uses two different strategies.

Sometimes, he explicitly mentions the name of an Olympian god, while making it clear that he is not really dealing with a god. In Cher. 26, for instance, Philo regards the Earth as the centre of the universe and the only part of the universe that stands firm. For that reason, so he argues, it has accurately ( $\varepsilon^{2} \imath \imath \beta \beta^{\prime} \lambda \omega \varsigma$ ) been called Hestia by men of old. The passage contains no trace of criticism against the ancient tradition, but it is very clear that Hestia is not understood as the goddess but as the 'standing-place' in the universe. The same approach can be found in Opif. 133, where Philo considers Earth to be a mother, adding that men of old apparently had the same view, as they called her 'Demeter', combining the name of mother with that of earth. Again, the name of the Olympian goddess is explicitly mentioned, but here too, she has lost her divine status. She is simply the Earth, which is also called All-mother, Fruit-bearer and Pandora. In such a perspective, Demeter and Pandora are one and the same, viz. the Earth. It is striking though that Philo thus seems to endorse an identification (Demeter $=$ Earth) which he explicitly rejected in Decal. 54-55 and Cont. 3 (T5 and T6). Yet this is no inconsistency on Philo's part. In the latter two passages, as we have seen, Philo rejects the identification because it deifies an element. ${ }^{27}$ In Opif. 133, on the other hand, he accepts the identification because (and to the extent that) it yields precisely the opposite dynamic: Earth is not deified, but Demeter is reduced to the level of Earth.

On other occasions, Philo is dealing with the divine realm, but strategically avoids naming the Olympian god. ${ }^{28}$ A case in point is Plant. 127-29, where Philo once again mentions a 


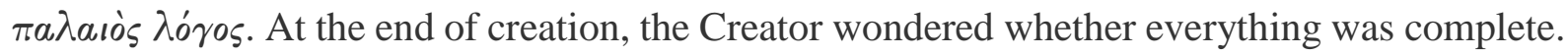
One of his interpreters $(\dot{\nu} \pi \circ \varphi \eta \tau \tilde{\omega} \nu)$ told him that there was only one thing lacking, that is, the word to praise the final result:

T7 The story runs that the Father of the universe on hearing this commended what had been said, and that it was not long before there appeared the new birth, the family of the Muses and hymnody, sprung from one of His powers, even virgin Memory, whose name most people slightly change and call her "Mnemosyne."

Philo's source of this old story is not entirely clear. Hesiod deals with the birth of the Muses in his Theogony (53-62), but his account lacks the specific cosmogonic framework that Philo mentions. ${ }^{29}$ Therefore, the hypothesis of a Pythagorean origin (via Posidonius) has been put forward. ${ }^{30}$ Anyhow, what matters here is that in Philo's version of the story, every mention of Olympus and its inhabitants is systematically omitted. Zeus becomes the Father of the Universe

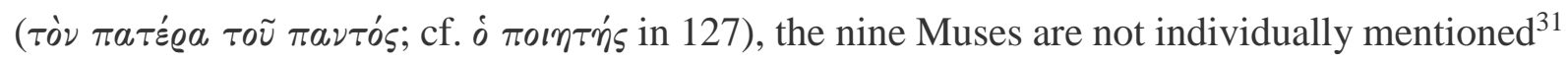

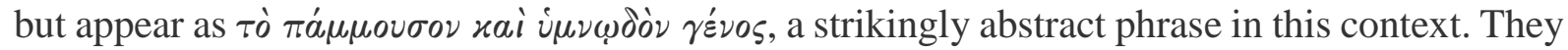

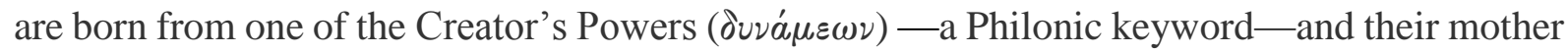
is Memory: Mnèmè rather than Mnemosyne, again an abstract term. Throughout the story, then, Philo translates pagan material in terms that better fit in with his own conception of God. In other words, he replaces polytheism by a monotheistic outlook.

Philo then concludes his account with a general phrase: "so runs the myth of the men of old"

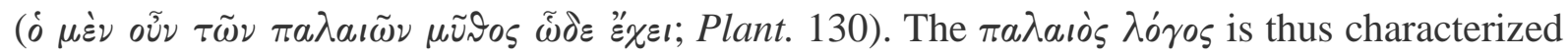
as a $\mu \tilde{v} \mathcal{O}$, though not as a deceptive $\pi \lambda \dot{a} \sigma \mu a \mu$ í̃ov. On the contrary, it proves to be perfectly

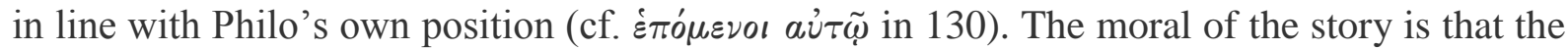
work most appropriate to God is transferring benefits, but that most appropriate to creation is 
thanksgiving. And thus, the Olympian gods, who are systematically pushed into the background in this story, have at the end completely disappeared from sight.

An analogous case is Prob. 19, where Philo, in the context of a discussion of the truly free man, quotes Sophocles’ verse “God (શॄós) and no mortal is my sovereign” ( $\operatorname{Tr} G F$ 4, fr. 755). Again, no trace of an individual Olympian god is to be found here, and this may well be the result of a deliberate choice of Philo. For Sophocles was not speaking of God in general terms, but actually named Zeus. Colson suggests that the reading 'God' may be of a later date and that Philo himself quoted Sophocles correctly. ${ }^{32}$ This, however, is rather implausible. We have already seen how Philo as a rule prefers to speak in more general terms when he comments positively on the Olympian gods (cf. Somn. 1.233 and Plant. 127-29 discussed above) and that he does not hesitate to reorient traditions towards his own perspective. ${ }^{33}$ In all likelihood, he followed the same approach here as well. In any case, he further develops the idea of the

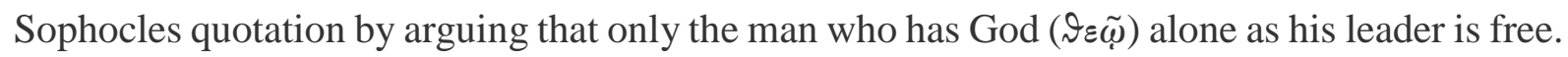

The same strategy occurs again in $L A 1.15$, where Philo discusses the number seven, the only number within the decade that neither produces nor is itself produced by any other number within the decade:

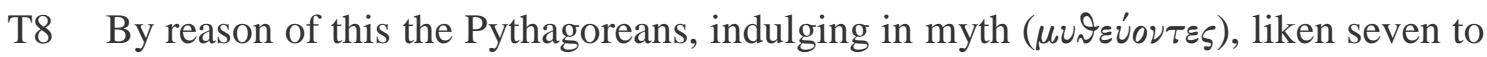
the motherless and ever-virgin Maiden, because neither was she born of the womb nor shall she ever bear. ${ }^{34}$

Here, the reference is clearly to Athena and the Pythagorean position is also understood as a kind of myth. Again, Philo avoids mentioning the Olympian goddess by name: Athena has

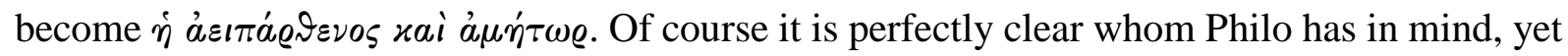
his phrasing rather evokes an abstract principle than an anthropomorphic goddess. 
By means of the two strategies analysed above, Philo thus manages to recover the truth of some ancient stories: either he mentions the gods by name but suggests that he is not really dealing with gods, or he omits their names altogether. There are only two exceptions where Olympian gods are introduced by name and yet positively regarded as gods.

The first passage is Opif. 100, which again deals with the peculiar character of the number seven. This is a close parallel to T8, but this time, Philo refers to the goddess by name:

T9 It is the nature of 7 alone, as I have said, neither to beget nor to be begotten. For this reason other philosophers liken this number to the motherless and virgin Nike, who is said to have appeared out of the head of Zeus.

For once, we read a clear reference to the Olympian goddess and to the story of her remarkable birth. ${ }^{35}$ Moreover, the whole theory about the seven is perfectly reconcilable with Philo's own convictions and is no longer characterized as a myth. It is rather introduced as the view of other

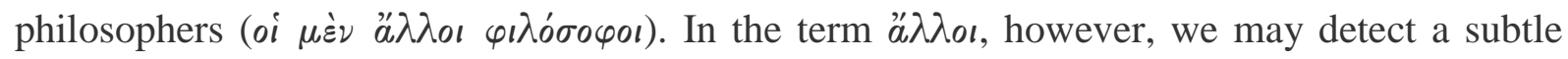
distance: these philosophers may defend the same idea, but they apparently have other ideological starting points. ${ }^{36}$ This is the farthest Philo can go in his reconciliatory approach. This passage goes beyond the usual avoidance of criticism (T3) and shows genuine appreciation. Only the term $a^{\prime} \lambda \lambda_{o} \iota$ is a clear hint that the absolute hierarchy elaborated in $\mathrm{T} 1$ and $\mathrm{T} 2$ remains in full force.

The second passage is Prov. 2.15. There, Philo underlines that God is not a cruel tyrant but a kind king and a loving father. For that reason, Homer called Zeus the father of gods and men. In this case, a modification of the text as in the Sophocles quote discussed above was not possible, since the Homeric verse was not merely widely known but also derived its meaning

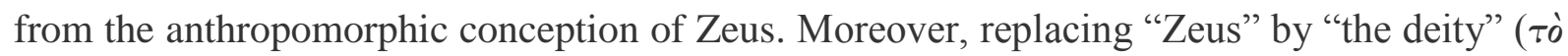


خeĩov) would not help Philo's case, for even then, his title of "father of gods and men" would keep the polytheistic perspective intact. Philo had only two options: either omit the verse altogether ${ }^{37}$ or drain the cup. Philo chose the latter option. He presumably found the Homeric verse interesting because it expressed the general conception of God as a father very well. It is this idea on which Philo focuses and which he elaborates in what follows. Its original polytheistic context almost immediately disappears again. Nevertheless, it is characteristic of Philo's open-mindedness and versatility that he took the opportunity to benefit from this grain of pagan wisdom. ${ }^{38}$

\section{A special case: On the Embassy to Gaius}

Philo's treatise On the Embassy to Gaius deserves a treatment on its own. The work contains a lengthy section about Gaius' ambition to pursue divine honours, and there we find several other strategies which throw further light on Philo's reception of the twelve Olympian gods. Philo presents Gaius' insane aspirations as a gradual evolution. The emperor began by aiming at the honours of demigods like Dionysus, ${ }^{39}$ Heracles and the Dioscuri (Legat. 78-92). This section about lower deities need not detain us here, even more so since Philo's argumentative approach in it resembles that of the following sections, which concern Gaius' attempts to identify himself with Hermes, Apollo and Ares. ${ }^{40}$ Thus the Olympian gods enter the discussion.

Philo relates how Gaius took over the typical attributes of the gods: the equipment of Hermes the messenger (his staff and sandals; 94), the outfit of Apollo as sun god (including sun-rays, bow and Graces; 95), and the military dress of Ares (with sword, helmet and shield; 97). In Philo's view, all this is a mere travesty of the divine symbols, for in Gaius' case, these attributes lack any fundamentum in re. His wicked behaviour is diametrically opposed to the virtue of the gods, as every spectator immediately understood (98). The basic idea which serves as the point 
of departure for Philo's attack on Gaius in this section, and which gains the power of a communis opinio through Philo's clever focalization in this passage, is thus that external divine features symbolize the virtues and benefactions of the gods. Philo's only task then is to examine whether Gaius has conferred the same benefactions on his people as Hermes, Apollo and Ares. And of course, the answer is an obvious and simple no.

Hermes' winged sandals show that the god quickly brings good news, whereas his herald's staff is a symbol of reconciliation in war (99-100). Gaius on the contrary was usually the bringer of bad news and the cause of many wars (101-102). In short, by assuming Hermes' attributes, Gaius shows himself to be an impostor ( $\left.\psi \varepsilon v \delta \omega^{\prime} \nu \mu_{0}\right)$. It is quite striking that in this whole passage, Philo's understanding of the god Hermes is unreservedly positive. Philo deliberately selects a few elements from the tradition and interprets them from a biased perspective. A pagan could generally agree that Hermes' winged sandals indeed express the swiftness of the god, ${ }^{41}$ but not every pagan would share Philo's Platonic conviction that the god, just like the sage, was only a messenger of good tidings. From Homer on, Hermes also had a more negative side, for instance as the cunning god of the thieves. ${ }^{42}$ Again, Philo's positive interpretation of Hermes' herald's staff is not without parallels, ${ }^{43}$ but is no less one-sided. ${ }^{44}$ And thus, we get a remarkably positive image of the Olympian god, an image that is in line with Philo's Platonic convictions and that is not even very offensive to his own Jewish conception of God, for the God of Scripture, of course, is no less the source of benefactions.

A similar argumentative strategy occurs in the next section concerning Apollo. Again, Philo systematically opposes the god and his miserable would-be alter ego. Apollo loved light, Gaius needed darkness (103). The god held the bow in his left and the Graces in his right hand, preferring boons to punishment, whereas Gaius should rather carry the bow in his right hand and throw away the Graces (104-105). As a god of medicine and prophecy, Apollo proved to be a benevolent helper of human beings, whereas Gaius only thinks of destruction and 
foretelling disaster (106-110). Again, we thus find the same selective and positive interpretation of the Olympian god. That Apollo also caused the plague is glossed over, and that the god's oracles were usually ambiguous and concealed as much as they revealed is likewise left out. Philo even suggests that thanks to Apollo's oracles, a man can see the future with his mind "as clearly as he sees what lies before him with the eyes of his body" (109). Oedipus or Croesus could tell a different story about Apollo Loxias! In short, Philo's view of Apollo here resembles his view of Hermes in the previous paragraphs: we get a high minded and strikingly positive image of the Olympian god, well in line with Platonic philosophical standards.

Even in the case of Ares, Philo adopts the same line of argument. This is not evident as such, for it is not so easy to give such an exclusively positive interpretation of the war god, and it is probably no coincidence that this section is the shortest of the three. Philo underlines the opposition between Ares' strength and Gaius' weakness (111-12) and then distinguishes

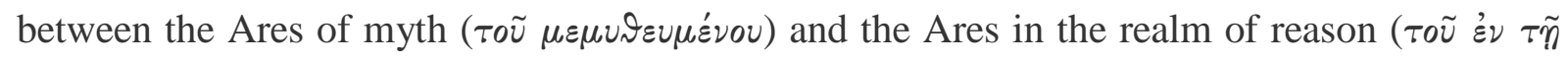

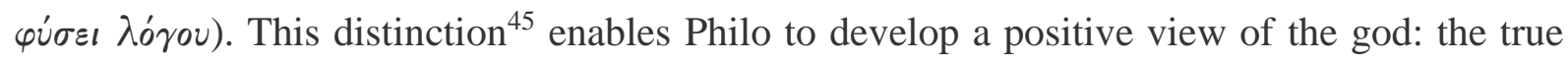
Ares turns out to be the champion of the wronged, as appears from his name, which is derived

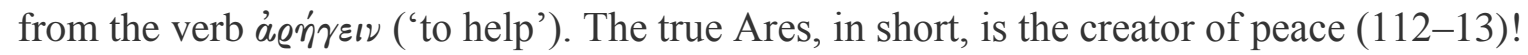

As far as I know, this etymological interpretation is unparalleled in extant literature. Plato

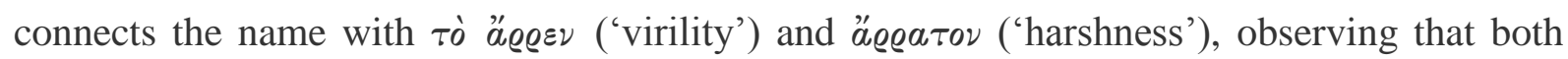
explanations are fitting for a war god ( the name as àvaıย́tฑs ('murderer') (SVF 2.1094)—an explanation which Plutarch later considers an accusation of the god (Amatorius 757B). Heraclitus links the god's name with å@

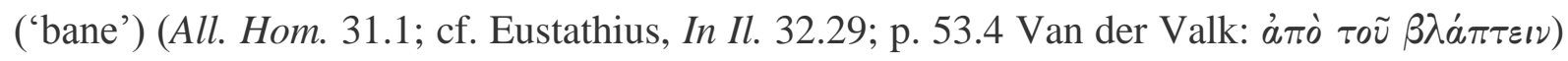
and elsewhere associates him with madness $(54,2)$ and vice $(54,6)$ Cornutus provides a list of possible etymologies, ${ }^{46}$ but Philo's explanation is not mentioned. The etymology "A@ns

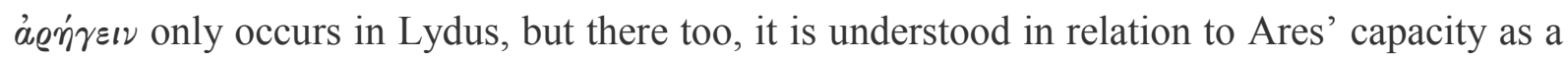


war god: the god is seen as a helper in occurrences of violence and fighting (Mens. 4.34). Philo's peculiar view of Ares as a god of peace is at odds with the whole ancient tradition and is obviously conditioned by the demands of his argument. He needed such a positive image of the god in order to oppose it to Gaius' cruelty. In other words, because Gaius was a friend of wars (Legat. 113), Ares had to become the god of peace.

The question remains, however, why this argumentative tour de force was necessary. Why did Philo opt for this argument, which implies such a positive interpretation of the Olympian gods, although he had a valid alternative? For he could also have argued that Gaius' crimes resembled all the $\pi \lambda a \dot{\sigma} \sigma a \tau a \mu$ í̃ov about the Olympian gods. With such an argument, he would have killed two pagan birds with one stone. Why then being so positive about the Olympians? In my view, this argument yields several important advantages.

Firstly, the diametrical opposition between the Olympian gods and Gaius lays more emphasis on the latter's wickedness. A rhetorical synkrisis that is systematically elaborated, ${ }^{47}$ adding different examples to the list, brings about a black and white characterization that strongly underscores Gaius' evil nature. This effect is even enhanced by another contrast, viz. the opposition between Gaius' later depravity and the promising beginning of his reign. For at that early moment, everybody was thinking of the reign of Cronus, which suddenly did no longer appear to be a $\pi \lambda a ́ \sigma \mu a \mu$ í̃ov (Legat. 13). In his virtuous period, then, people could associate Gaius with the world of the gods, as his conduct expressed the positive aspects of the polytheistic tradition. This early success obviously casts a dark cloud over his later degeneration.

Secondly, we can find in this section of On the Embassy to Gaius the influence of a wellknown polemical strategy that is often found in ancient philosophical discussions, viz. adopting the opponent's view in order to refute it from the inside. In this case, Philo the Jew endorses the pagan perspective for the sake of his argument. He develops a positive view of the Olympian 
gods and then opposes this view to the behaviour of the pagan Gaius who claims to imitate them. The blatant contradictions which soon appear, suffice to refute Gaius' silly claims. The strategy often returns in authors like Cicero, Plutarch, Sextus Empiricus and many others. In Philo it occurs rather seldom, but an interesting parallel can be found in Aet. 68. There, Philo attacks the myth of the so-called 'Sown Men' ( $\Sigma \pi a \varrho \tau o i)$. They were sown by Cadmus, the founder of Thebes, and appeared out of the earth in full armour. Philo objects: "what smith was there on earth, or a Hephaestus so powerful as to prepare full suits of armour straightaway?" Of course, Philo himself did not believe in Hephaestus as the smith of the gods, but he for the time being endorses the view of the mythmakers and then points to an inconsistency that undermines their whole story. A similar strategy, but much more elaborated, returns in the above examined passage from On the Embassy to Gaius, where Philo uses elements of the pagan tradition against the pagan Gaius. If this is true, the implication is that the positive view of the Olympian gods in this section primarily serves a polemical purpose and thus should not be regarded as evidence of Philo's own positive appreciation of the Olympians.

Thirdly, Philo here successfully avoids offending the religious feelings of both the Jews and the pagans. On the one hand, we have seen that he reorients the tradition about the Olympian gods towards a Platonic perspective that is closer to his own Jewish conception of God. On the other hand, the pagans can hardly be offended by Philo's positive interpretation of their gods. We thus once again detect a touch of pragmatism in Philo's approach. His 'benevolent' reception of the Olympian gods is fully consistent with the course he recommends in T3, and will thus, in Philo's own view, in turn create goodwill for the Jews and their God. But Philo here even goes beyond the directions of T3, as he does not merely avoid abusing the gods, but even develops a distinctly positive discourse, the effect of which is even enhanced in the next section. There, Philo argues that the Jews were the only ones who protested against Gaius' mad aspirations and were therefore especially hated by the emperor (Legat. 115-18). Whereas all 
other nations flattered Gaius, the Jews were the only ones who refused to do so and thus de facto did justice to the pagan gods. The suggestion is clear enough: at that moment, the Olympian gods could only expect help from the Jews!

\section{Conclusion: between words and silence}

Thus, we end up with the striking conclusion that, in spite of all his criticism, the Olympian gods should be grateful to Jews like Philo. And this tells much about Philo's clever approach towards the pagan gods.

There can be no doubt that Philo utterly rejected belief in the twelve Olympian gods. All the stories about them are mere $\pi \lambda \dot{a} \sigma \mu a \tau a \mu$ í̃ov. They are false products of sophists and mythmakers and irreconcilable with Jewish Scripture. But strikingly enough, this view is only rarely made explicit, at least as far as individual gods are concerned. Philo criticises polytheism in general and he now and then refutes problematic interpretations of the gods, but always refrains from attacking the gods themselves. On this point, he prefers to keep silent, although we should not doubt about his hidden convictions: dum tacet, clamat.

When he occasionally mentions the Olympian gods, his comments are usually positive. Sometimes, this appreciation is merely pour le besoin de la cause, as in On the Embassy to Gaius. In other cases, specific elements of their myths can throw light on a passage from Scripture or an aspect of the Law, or can be useful in a moral pedagogical context. Such a positive approach avoids offensive insults and thus contributes, in Philo's view, to the good reputation of the Jews and their God. It rests on a creative selection of elements that can be appropriated (usually with some modification) and used within Philo's own argument. These elements receive full attention, whereas all the rest fades into the background. We should not forget indeed that in his reception of the Olympian gods, Philo simply hushes up by far the 
greatest part of the available material: dum clamat, tacet.

In that sense, Philo's reception of the Olympians shows a highly sophisticated combination of tacere and clamare, of diplomatic silence and strategic shouting. We may add, though, that both Philo's tacere and his clamare were an eloquent eulogy of the only true God.

7. Works quoted

Alesse, F., ed. 2008. Philo of Alexandria and Post-Aristotelian Philosophy. Leiden - Boston. Berthelot, K. 2011. "Philon d'Alexandrie, lecteur d'Homère: quelques éléments de réflexion." In Balansard, A., Dorival, G. and Loubet, M. eds., Prolongements et renouvellements de la tradition classique: 145-57. Aix-en-Provence.

— 2012. "Philo and the Allegorical Interpretation of Homer in the Platonic Tradition (with an Emphasis on Porphyry's De antro nympharum." In Niehoff, M. R. ed., Homer and the Bible in the Eyes of Ancient Interpreters: 155-74. Leiden.

Billings, T. H. 1919. The Platonism of Philo Judaeus. Chicago.

Bolognesi, G. 1970. "Postille sulla tradizione armena delle Quaestiones et solutiones in Genesin di Filone." AGI 55: 52-57.

Bréhier, E. 1907. Les idées philosophiques et religieuses de Philon d'Alexandrie. Paris.

Cohn, L. and S. Reiter 1915. Philonis Alexandrini operae quae supersunt. vol. 6. Berlin.

Colson, F. H. 1941. Philo. Edited with an English Translation in Ten Volumes (and Two Supplementary Volumes). vol. 9 [LCL]. London - Cambridge (MA).

Cumont, F. 1919. “Un mythe pythagoricien chez Posidonius et Philon.” $R P h$ 43: 78-85.

Dillon, J. 1977. The Middle Platonists. A Study of Platonism 80 B.C. to A.D. 220. London.

Edwards, M. J. 1990. “Atticizing Moses? Numenius, the Fathers and the Jews.” VChr 44: 6475. 
Friesen, C. J. P. 2015a. Reading Dionysus. Euripides' Bacchae and the Cultural Contestation of Greeks, Jews, Romans, and Christians. Tübingen.

— 2015b. 'Hannah's 'Hard Day' and Hesiod's 'Two Roads': Poetic Wisdom in Philo's De ebrietate." JSJ 46: 44-64.

Goldenberg, R. 1997. “The Septuagint Ban on Cursing the Gods.” JSJ 28: 381-89.

Heinemann, I. 1932. Philons griechische und jüdische Bildung. Kulturvergleichende Untersuchungen zu Philons Darstellung der jüdischen Gesetze. Breslau.

Jacobson, H. 2004. “A Philonic Rejection of Plato.” Mnemosyne 57: 488.

Kamesar, A. 1998. "Philo, the Presence of "Paideutic" Myth in the Pentateuch, and the “Principles" or Kephalaia of Mosaic Discourse." SPhA 10: 34-65.

— 2009. "Biblical Interpretation in Philo." In Id. ed., The Cambridge Companion to Philo: 65-91. Cambridge.

Koskenniemi, E. 2010. "Philo and Greek Poets.” JSJ 41: 301-22.

Lamberton, R. 1986. Homer the Theologian. Neoplatonist Allegorical Reading and the Growth of the Epic Tradition. Berkeley - Los Angeles - London.

Lévy, C., ed. 1998. Philon d'Alexandrie et le langage de la philosophie. Actes du colloque international organisé par le Centre d'études sur la philosophie hellénistique et romaine de l'Université de Paris XII-Val de Marne (Créteil, Fontenay, Paris, 26-28 octobre 1995). Turnhout.

Lincicum, D. 2013. “A Preliminary Index to Philo's Non-Biblical Citations and Allusions.” SPhA 25: 139-67.

Martin, M. 2003. "Philo's Use of Syncrisis: An Examination of Philonic Composition in the Light of the Progymnasmata." Perspectives in religious studies 30: 271-97. 
Méasson, A. 1980. "Un aspect de la critique du polythéisme chez Philon d'Alexandrie: les

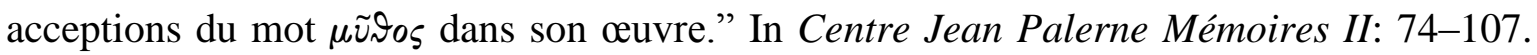
Saint-Étienne.

Niehoff, M. R. 1998. “Philo’s Views on Paganism.” In Stanton, G. N. and Stroumsa, G. G. eds., Tolerance and Intolerance in Early Judaism and Christianity: 135-58. Cambridge.

— 2012. "Philo and Plutarch on Homer." In Ead. ed., Homer and the Bible in the Eyes of Ancient Interpreters: 127-53. Leiden.

Nieto Hernández, P. 2014. "Philo and Greek Poetry." SPhA 26: 135-49.

Pease, A. S. 1958. M. Tulli Ciceronis De natura deorum Libri III, vol. 2 : Libri secundus et tertius. Cambridge (MA).

Pelletier, A. 1972. Philon d'Alexandrie. Legatio ad Caium. Introduction, traduction et notes. Paris.

Runia, D. T. 1986. Philo of Alexandria and the Timaeus of Plato. Leiden.

— 1993. "Was Philo a Middle Platonist?” SPhA 5: 112-40.

— 2001. Philo of Alexandria. On the Creation of the Cosmos according to Moses. Introduction, Translation and Commentary. Leiden - Boston - Köln.

Sandelin, K.-G. 1991. "The Danger of Idolatry According to Philo of Alexandria." Temenos 27 : 109-50.

Schwartz, J. 1971. "Philon et l'apologétique chrétienne du second siècle.” In Caquot, A. and Philonenko, M. eds., Hommages à André Dupont-Sommer: 497-507. Paris.

Simon, M. 1976. “Jupiter-Yahvé. Sur un essai de théologie pagano-juive.” Numen 23: 40-66.

Smallwood, E. M. 1970. Philonis Alexandrini Legatio ad Gaium. Edited with an Introduction, Translation and Commentary. Leiden.

Sterling, G. E. 1993. "Platonizing Moses. Philo and Middle Platonism.” SPhA 5: 96-111.

Tobin, T. H. 1993. "Was Philo a Middle Platonist? Some Suggestions.” SPhA 5: 147-50. 
Whittaker, J. 1967. “Moses atticizing.” Phoenix 21: 196-201.

Wolfson, H. A. 1948. Philo. Foundations of Religious Philosophy in Judaism, Christianity, and Islam. Cambridge (MA).

\footnotetext{
${ }^{1}$ Thus Numenius, fr. 8 des Places (= Eusebius, PE 11.10.14); cf. Whittaker 1967 and Edwards 1990.

${ }^{2}$ Seminal monographs include those of Bréhier 1907, Heinemann 1932 and Wolfson 1948. They have been followed by many detailed studies, up to the present.

${ }^{3}$ All translations are adopted from the LCL (sometimes slightly modified).

${ }^{4}$ A convenient list of quotations and references can now be found in Lincicum 2013.

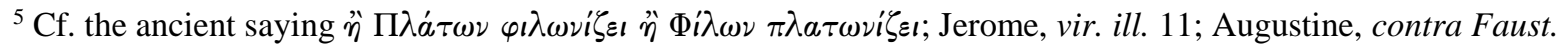
12.39; Photius, Bibl. cod. 105, 86b25-26; Suda 1.10.16 and 4.737.16.
}

${ }^{6}$ Among the many studies of Philo’s Platonism may be mentioned Billings 1919; Dillon 1977: 139-183; Runia 1986 and 1993; Sterling 1993; Tobin 1993. For the influence of other philosophical traditions, see esp. Alesse 2008; cf. also the studies collected in Lévy 1998.

${ }^{7}$ This does not imply, however, that Philo there only uses Homer for the sake of literary embellishment, as is argued by Lamberton 1986: 49 and 61 and by Koskenniemi 2010: 307-308. That even references to well-known

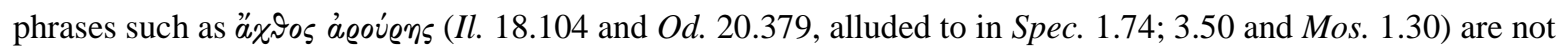
merely added for the sake of ornatus is shown by Nieto Hernández 2014: 144-148. For Philo's creative use of Homer, see esp. Berthelot 2011 and 2012; Niehoff 2012; Nieto Hernández 2014.

${ }^{8}$ Berthelot 2012: 158.

${ }^{9}$ See, e.g., Opif. 171; Heres 169; Virt. 214 and 221; $Q G$ 1.36; QEx 2.2. Cf. also the seminal article of Sandelin 1991, who deals with the broader theme of idolatry.

${ }^{10}$ Praem. 162; Ebr. 110; Fug. 114. In Migr. 69, polytheism is opposed to atheism, but there too, both are rejected.

${ }^{11}$ Conf. 42 and QEx 2.36.

${ }^{12} Q G 1.36$.

${ }^{13}$ See esp. Méasson 1980. On Philo's attitude towards Greek mythology, see also Wolfson 1948: 32-36.

${ }^{14}$ Cf. Goldenberg 1997. 
${ }^{15}$ And see also Mos. 2.205, where Philo argues that we should not speak insultingly of idols, since none of Moses' disciples should make it a habit of treating lightly the name of 'god', as it is a title worthy of the highest respect and love. This is an additional argument, concerning a different Scriptural passage (Lev. 24:15-16).

${ }^{16}$ In Prov. 2.34-39, Alexander criticizes the poets for having told false stories about the gods. In this context, he refers to ignoble features or conduct of Hephaestus, Aphrodite and Hera. But this is no direct criticism of the gods, only of the way in which they are represented by the poets. Moreover, Philo himself disagrees with Alexander and defends the poets by means of an allegorical interpretation (Prov. 2.40-41).

${ }^{17}$ Niehoff 1998: 138.

${ }^{18}$ Although it is fair to say that Philo is capable of (almost) anything, as appears from his treatise On Noah's work as a planter, which includes a full treatise on the philosophers' opinions about drunkenness.

${ }^{19}$ See on this Kamesar 1998: 35 and 2009: 79.

${ }^{20}$ See on both passages also Schwartz 1971, who interprets them in light of later Christian sources.

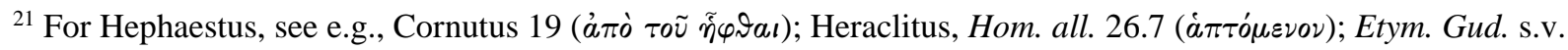

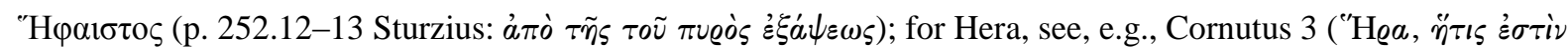

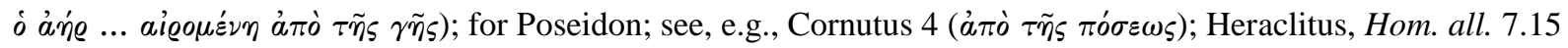

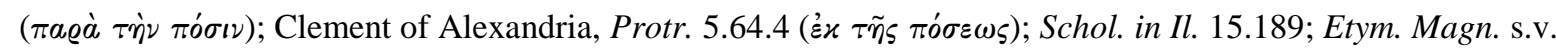

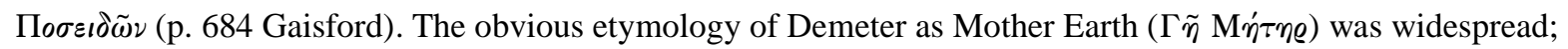
see, e.g., Plato, Crat. 404b8-9; Cicero, nat. deor. 2.67; Cornutus 28; Sextus, AM 9.189; much more material can be found in Pease 1958: 722.

${ }^{22}$ And this is true for myths in general; see Méasson 1980, whose view, however, is too absolute. Passages such as Aet. 127, QG 4.6 and Somn. 1.151 (discussed above) show that mythological stories about the Olympian gods can occasionally be interpreted more allegorico, and the same holds true for other myths. We may recall Philo's allegorical interpretation of Scylla as immortal vice (based on Homer, Od. 12.118) in Det. 178, Fug. 61 and $Q G$ 1.76, or his moral allegory of the myth of the Hydra as a story about the difficulties of conquering undying vice (Somn. 2.14-15).

${ }^{23}$ The reference is to Homer, Odyssey 17.485-487. The same Homeric verses are also mentioned in $Q G 4.2$ (cf. Bolognesi 1970 for a discussion of the Armenian text of this passage).

${ }^{24}$ This is a point that has repeatedly been made in scholarly literature, see, e.g., Kamesar 1998: 41; Jacobson 2004; Niehoff 2012: 131-132. 


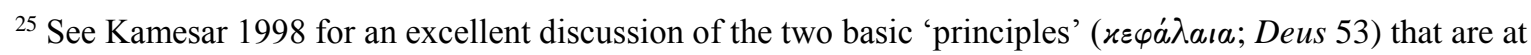
stake in these two passages.

${ }^{26}$ Cf. Niehoff 2012: 132.

${ }^{27}$ Cf. also Aet. 66, where Philo builds an argumentum ex absurditate on the idea of a personified earth.

${ }^{28}$ See, e.g., Deus 60 [allusion to Zeus] and Mos. 1.36 [again allusion to Zeus, according to Bréhier 1907: 74]. In Somn. 1.103, Bréhier 1907: 107-111 detects an allusion to Hermes.

${ }^{29}$ That Philo's reception of Hesiod can be quite creative, however, is shown by Friesen 2015a.

${ }^{30}$ By Cumont 1919.

${ }^{31}$ Contrast Hesiod, who mentions all nine by name (Th. 77-79).

${ }^{32}$ Colson 1941: 20-21, note a, whose argument rests on a parallel passage from Ambrose (sc. Epist. 37.28; CSEL 82, p. 57.1): "As Ambrose is not likely to have known the line from any other source, there is certainly some reason to suppose that he found Zeì in his text of Philo.” Cf. also Cohn - Reiter 1915: 5.

${ }^{33}$ It is true, however, that Philo's position here remains somewhat ambivalent, due to the addition of the phrase

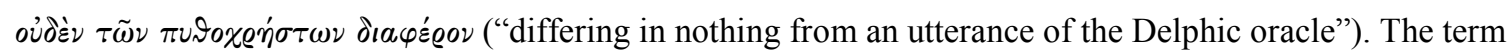
$\pi \cup$ จ $0 \chi \varrho \eta^{\prime} \sigma \tau \nu$ is very rare in Philo's works (apart from this passage, it only occurs in Prob. 160) and is obviously rooted in pagan culture.

${ }^{34}$ Cf. also Mos. 2.210, where the same material is used.

${ }^{35}$ Although, strictly speaking, the name of Athena is not mentioned; cf. Heinemann 1932: 111 about this passage: "also natürlich Pallas Athena, wenn auch Philon taktvoll genug ist, den Namen nicht offen zu nennen, um dem Sabbat nicht eine heidnische Schutzpatronin zu geben.”

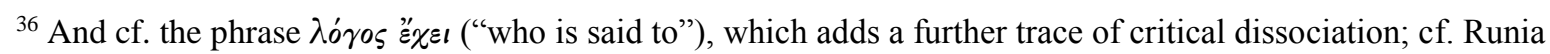
2001: 273 .

${ }^{37}$ This is what Eusebius later did ( $P E$ 8.14.3) - the reference to Homer has only been preserved in the Armenian text.

${ }^{38}$ We may add that Philo elsewhere also speaks of God as the God "not only of men but also of gods" (Spec. 1.307 and 2.165; Mos. 2.260). After all, the Septuagint translation of Deuteronomy also refers to the "God of gods and Lord of lords" (10:17); cf. Wolfson 1948: 38-39 and 173-174.

${ }^{39}$ It is striking that Dionysus is ranged by Philo among the demigods. On his view of Dionysus, see Friesen 2015b: 86-93 (on the relevant section from On the embassy to Gaius) and 198-206 (concerning On 
drunkenness). Friesen correctly shows that Philo's image of Dionysus fails to do justice to the essence of the god's nature.

${ }^{40}$ According to Smallwood 1970: 200, "[i]t is remarkable that Philo is silent in 93-113 about the matter most stressed by other authorities, namely Gaius' equation of himself with Jupiter. To this he merely refers without comment, when he talks later of Gaius' decision to turn the Temple in Jerusalem into a temple dedicated to 'Gaius, the New Zeus Epiphanes' (346).” See Pelletier 1972: 129n4 and Simon 1976: $43-44$ for possible explanations.

${ }^{41}$ See, e.g., Servius, Aen. 8.138.

${ }^{42}$ See, e.g., Homer, Il. 20.35 and Od. 19.396-397; Hesiod, Op. 77-78.

${ }^{43}$ See, e.g., Orphic hymn 28.7; Servius, Aen. 8.138.

${ }^{44}$ Cf. Smallwood 1970: 200: “The herald's staff was one of his attributes because, as a somewhat subordinate god, he played the part of messenger for Zeus."

${ }^{45} \mathrm{Cf}$. Congr. 57, where an analogous distinction is made concerning Hades.

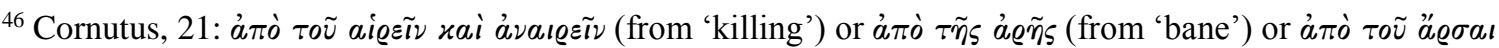
(from 'joining': this explanation is $\varkappa a \tau$ ' ह่ $\nu a \nu \tau i \omega \sigma \iota \nu$, 'by contrariety', as if we may mollify the god by giving him this name).

${ }^{47}$ For Philo's familiarity with and use of the rhetorical technique of synkrisis, see Martin 2003. 